\title{
THE SIGNIFICANCE OF SULH IN THE SYARIAH COURT
}

\author{
Nur Syasya Binti Rossiman \\ Sultan Sharif Ali Islamic University (UNISSA) Brunei Darussalam, \\ Email: Syasya.rossiman@hotmail.com
}

\begin{abstract}
Sulhis a form of alternative disputes resolution (ADR) in the context of Islamic law. Due to the increasing rates of divorces, family conflicts and custody claims, the Syariah Court made a decision in introducing a tributary channel in the legal system that allows people to negotiate and reach an amicable agreement and settlement without court intervention, which is known as Sulh. It will be a good platform for disputants to settle things accordingly without having to wait for a period of time. Thus, It acts as a catalyst in processing cases and resolving disputes among disputants. However, there are still numbers of people who do not know the existence of Sulhand its significance. This is due to the lack of exposure, knowledge and the term itself"Sulh" in arabic makes it even harder to be understood among people whom are not well-versed in arabic language. As a result, people are restricted to one court-assisted method when there's actually more tributaries to the problem-solving. Although it is an ancient method but it is efficient in a way it offers disputants a win-win situation and satisfactions. Having said that, this paper will further explain the history of Sulh, the significance of its application and practice in the decision making as a way forward in resolving marriage conflicts or family matters. Furthermore, this paper employs a qualitative approach and the data collection will be based on library and documentations. Hence, the findings of this paper is based on the literature reviews and past studies' of previous researchers on Sulh.
\end{abstract}

Keywords: Sulh, Disputants, Syariah Court, Alternative Disputes Resolution

\section{INTRODUCTION}

Sulh is one of the mechanisms for dispute resolution or namely Alternative Dispute Resolution (ADR). The usage of Sulh is not recent but rather has been introduced long ago since the advent of Islam. Indeed, there has been some historical remarks on the implementation of Sulh during the Caliphate rulers and even now amongst the Malay people. It means that this methodis still used in the society to resolve disputes. Typically, the Malay society prefers the method of negotiation to litigation; this is due to the practice of high tolerance among the disputants in resolving their disputes. Even though, they are in an argument state, but the value of respect for each other is still put on the line throughout the entire process.

Looking back during the early ages of Islam, if there were an 
occurrence of disputes among the people, they would elect a mediator to conduct the judgement (tahkim) between them. One of the famous disputes during Rasulullah's reign may Peace BeUpon Him (PBUH) was the placing of the blackstone (حجر الأسود). Many of the Rulers debated on the person whom should have the honorof placing the blackstone in its place. After several discussions between the Arab rulers, they decided to appoint a mediator which was Rasulullah $P B U H$ to resolve the matter.As Rasulullah was required to make a call, He then impressed everyone with his decisions to let everyone (the Arab rulers) tohold every edge of the cloth put under the blackstone and together put it in its rightful place.

This shows that Sulhhas been practiced long ago by Rasulullah (PBUH) himself then followed by Sahaba, Caliphs ruler and until now among the Malay community, which somehow has become their traditions in solving any occurrence of disputes in their circles. We can denote that Sulh is one of the successful inherited mechanisms in resolving disputes from the early age and still blooming in this era.

Similarly, to the Malay community, the people will elect among the family members first to be the mediator between them and consult the elected mediator regarding their matter or concerns. However, if the problem or crisis still persists, both disputed parties will then refer the arguments to the head of village (ketua kampong) to give verdicts and resolve the matter accordingly and fairly with respect to both best interests. Having said that, this paper will focus on how Sulhis an advantage to the Syariah court and moreover its impact towards the backlog of cases that has been clogging the calendar of the Syariah court. Before going through the main part of this paper that is the significance of Sulhin the Syariah Court, let's take a look at its definition first. As the word Sulh itself is not a familiar word around, perhaps a brief definition of this Sulh in this paper may help in giving a better understanding of what Sulh inclusive of.

\section{DISCUSSION \\ Definition Of Sulh}

Imam An-Nawawi defines Sulhas ending a dispute, it is derived from an Arabic word (صلح) which means to be good, righteous or suitable. From here, maslaha (مصالحة) is derived that gives the meaning of reconciliation, negotiation, compromise or settlement. Sulh can also be defined simply as a termination of dispute or ending a dispute with an amicable settlement (Soadah, 2015). Where by, two parties agree to reach a settlement on their disagreements.

The scholars of Islam has divided the Sulh into several sections namely, The Sulh between Muslim and Non-Muslim, The Sulh between spouses (in marital disputes), The Sulh between the Just people and the 
Transgressors (Bughah), The Sulh in non-commercial and commercial disputes and etc. However, in this paper, It will only be focussing on the Significance of Sulh between disputants (spouses) in resolving marital disputes or conflicts.

\section{Emphasis Of Sulh In Al-Quran And Hadith}

The Qur'an has also mentioned Sulh as a way in resolving disputes:

$$
\begin{aligned}
& \text { وَإِانْ خِفْتُمْ شِقَاقَ بَيْنِهِمَا فَابْعَثُوا حَكَمًا مِنْ أَهْلِلِ وَحَكَمًا مِنْ أَهْلِهَا إِنْ يُرِيدَا إصْاكَحًا }
\end{aligned}
$$

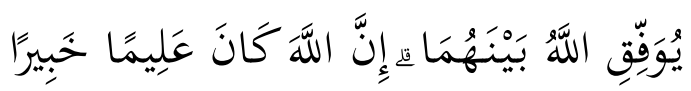

"If you fear a breach between them (husband and wife) appoint two arbiters, one from his family and the other from hers. If they wish for peace, Allah will cause their conciliation, for Allah hath full knowledge, and is acquainted with all things." (An-Nisa: 35).

The above verse signifies that, if the spouses are in great disagreement about their marriage, a third party intervention shall be introduced from both sides to reach a settlement or review any options that best suits them.

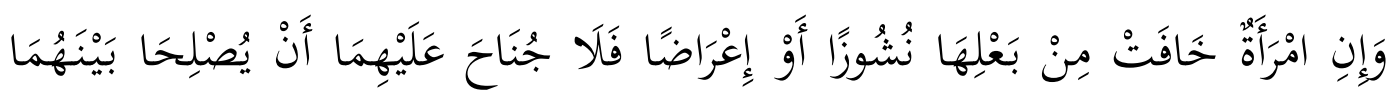

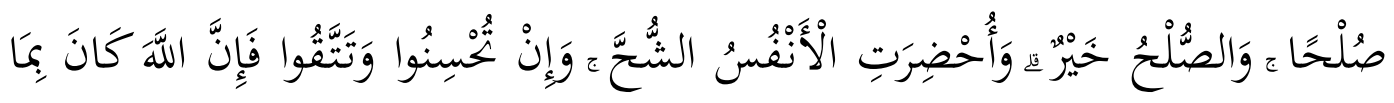

$$
\text { تَعْمَلُونَ خَبِيرا }
$$

"If a wife fears cruelty or desertion on her husband's part, there is no blame on them if they arrange an amicable settlement between themselves, and such settlement is best." (An-Nisa:128).

Hadith:

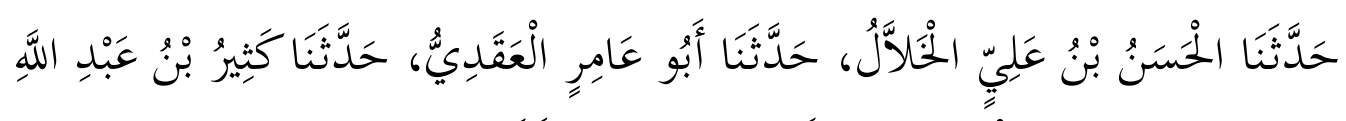

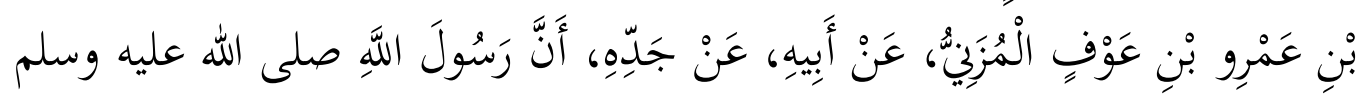

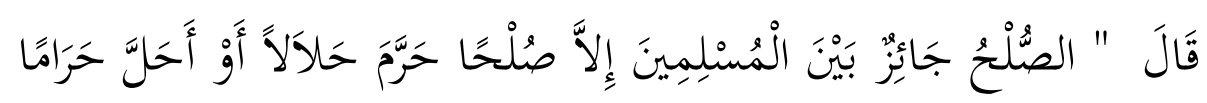

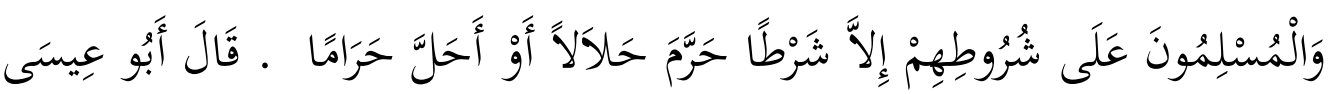

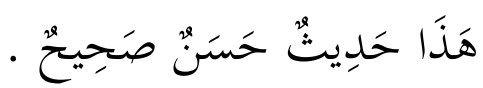

Kathir bin 'Amr bin 'Awf Al-Muzani narrated from his father, from his grandfather, that the Messenger of Allah said: "Reconciliation is allowed among the Muslims, except for reconciliation that makes the lawful unlawful, or the unlawful lawful. And the Muslims will be held to their 
conditions, except the conditions that make the lawful unlawful, or the unlawful lawful.

The hadith above shows that Sulh is permissible in resolving disputes as long as it is Shariah compliance; not making the unlawful lawful and vice versa.

\section{The Significance Of Sulh}

The concept of Sulh is applicable in almost every conflicts resolutions, it is not restricted to the management of family-disputes, marital conflicts but also commercial disputes and even politics. As the number of Mal cases (particularly divorce cases) are increasing by years, it is very alarming to see the numbers are getting higher and not lower. The increasing number of divorce cases are rather a global issue and an-on going problem that has been shared both in regional and national level.

Nevertheless, this Sulh is one of the tools that has the ability to reduce these numbers. In fact, Malaysia and Brunei have shared the same concerns in these alarming numbers of cases and adopted the similar measures to tackle these issues by introducing the Sulh method in the Syariahcourt.Basically, this paper will encompass the significance of Sulh in the Syariah court and how it helps the Syariahcourt in its administrative system.

\begin{tabular}{|c|l|l|}
\hline No. & Country & Divorce cases \\
\hline 1. & Malaysia & 171,252 \\
\hline 2. & Brunei & 369 \\
\hline 3. & Indonesia & 365,333 \\
\hline
\end{tabular}

Statistic figures of divorce cases recorded in 2016 for Brunei, Malaysia and Indonesia.

Statistically, in Brunei Darussalam, In the year 2017; the Mal cases have been recorded as high as 2101 cases (399 divorce cases) compared to in the year 2016, which is only 1389 (369 divorce cases) cases (Media permata, 2018). This is considered high in Brunei, given the population ratio is relatively smaller than Malaysia. On the other hand, Malaysia has recorded as high as 171,252 cases in 2016 (Utusan, 2017). While in Indonesia, it is recorded as high as 365,333 cases that year. This shows how gullible and vulnerable the marriage foundations among the Muslim communities. It is very saddening and disappointing at the same time to see these kinds of stories and issues are among the top issues facing the Muslim community.

In Malaysia, local news has explained that the main reason for this split up to occur among Muslim community ismainly because of miscommunications between spouses followed by financial burdens. Brunei Darussalam it self is no exception, as poor communications 
between husband and wife has become the main factor for most of divorce cases in the said country, followed by cheating as the second factor (Suhardi, 2018). This is where Sulh comes into the picture to reduce this on going conflict between spouses for a better future via an amicable settlement especially one that involves children. Poor communications can be improved with the help of this Sulh method and its processes involved. It is believed that with the implementation of Sulh in the judiciary system will cut down the time taken to resolve one's dispute and reach a settlement rather quickly with a win-win situation approach which will further elaborated in the next section.

Children are the nucleus of the country, they are the one whom will continue the legacy and develop the nation more. Often we see, Children too are the victim in these disputes and even worse being the one whose left behind the dark and not knowing what to do they are being dragged around the problem (Asmidah, 2015). However, this paper will focus on the Significance of Sulh in the Syariah Court in resolving conflicts with special reference to the findings and discussions from previous studies. It is highlighted that the Significance of Sulhcan be identified in various aspects through the settlement rate, the process-period, its cost-effective, the caucus session, the Sulh officers and the reduction of backlog cases.

\section{Settlement Rate}

The effectiveness of Sulhis highly depended on the settlement rate of the cases. For instance, if the disputants are settled in the Sulhsession, that shows that it is successful. This is because the dispute parties are willing to settle things without getting the court involved in their cases. However, if the disputants still unable to reach an agreement, then the case shall be referred back to the court for further assistance.

\begin{tabular}{|l|c|c|c|c|}
\hline Mahkamah & Daftar & Berjaya & Bicara & Tangguh \\
\hline Mahkamah Tinggi & 902 & 342 & 497 & 63 \\
\hline Mahkamah Rendah & 4420 & 3249 & 1090 & 81 \\
\hline Jumlah & 5322 & 3591 & 1587 & 144 \\
\hline Peratus & $100 \%$ & $67 \%$ & $30 \%$ & $3 \%$ \\
\hline
\end{tabular}

Statistics of Syariah court in Selangor from May 2002-2005.

The above statistic show the number of Sulh cases found in Selangor Syariah court from May 2002-2005. Based on the statistic, 3591 cases that is around $67 \%$ of the Sulh cases are successfully settled. This has proven that the method is quite effective especially in resolving cases. Another studies conducted by (Fuad and Jamilah, 2003) stated on their findings that after Sulh has been implemented at the Syariah court in Selangor, the settlement rate among disputants were very 
astounding.

Based on their statistical data from the month of May to December in 2002, they analysed that out of 803 cases which were referred to Sulh Officers, 492 cases were settled without court interventions $(61.7 \%)$. On the other hand, 235 cases $(29.26 \%)$ were brought to trials while the remaining of 76 cases $(9.46 \%)$ were still being processed in the Sulh event. This study was conducted in Selangor, inclusive of all states; Shah Alam, Klang, Kuala Langat, Kuala Selangor, Sabak Bernam, Petaling Jaya, Gombak Barat, Gombak Timur, Hulu Langat, Sepang and Hulu Selangor. Also another study conducted by (Soadah, 2015) also stated in her finding that the successful rate of Sulh was very high. According to her, the successful rate was $64 \%$, while the cases that are referred to trials were $34 \%$. Based on these findings from the previous studies, it strengthens more on the significance of Sulh in the Justice system especially when the settlement rate is very convincing. It shows that Sulhdoes play a vital role in the Islamic Governance namely in conflicts resolution.

\section{The Process period}

Usually during theSulh Session, there are certain procedures and guidelines need to be followed before conducting a SulhSession itself. For example in Brunei Darussalam, there are few outlines for disputants and concerned parties. Below are the processes involved:

\section{Process I}

The Registrar where the case is being trialled will:

a. Register and provide sulh files, and

b. Set a minute to the Registrar General to request the appointment of a Sulh Officer.

\section{Process II}

The Registrar General will appoint a Court Officer as Sulh Officer to handle the Sulh session.

\section{Process III}

The Sulh chairman will set the date for the Sulh Council through the Sulh Council Notice. The notice is a command to both parties to appear before Sulh Officer.

\section{Procedure IV}

The presence of the parties in front of the Sulh Officer will go through the following process:

a. Introductory Session, When both sides are present at the Sulh session, the Sulh Officer will make the introductory session to the parties and highlight the followings:

1) Sulh purpose and concept of peace 
2) Advantages of Sulh and the role of parties

3) Guide lines and courtesy during the Sulh session

b. Initial Presentation, Sulh Officer will give the parties an opportunity to make an initial presentation on is Brief information on the background of the facts of the dispute

c. Discussion: Sulh Officer will make a mutual discussion with both parties to identify:

1) Issues and problems that need to be resolved

2) The position of the parties and their respective interests,

3) Optional solutions for issues and problems

d. Private Session/Caucus: If it is necessary Sulh Officer will hold separate discussion sessions with each party on a rotational basis, ie if there is a deadlock in the discussion for:

1) Identify, generate and explore options for solutions

2) Checking the acceptability of the choices (reality test)

e. Results and Results:

The Sulh Officer will decide whether the parties have succeeded or did not resolve their dispute. If successful, a draft "Agreement of Consent" will be prepared which will be signed by both parties. The consent will then be submitted to the Syariah Judge for approval in Court as "Order By Agreement". According to the procedures above, the Sulh sessions can be less time-consuming depending on the mutual understanding in reaching an agreement. If the disputants willing to co-operate in this, the process-period will take up to only one Sulh session. Normally, the Sulh event may commence in just 3 months and decisions will be made at this point either to end it with an amicable settlement or proceed to trials (So'adah, 2015).

\section{Cost-Effective}

Economically, this method has aided the whole process with zero cost, which means that the disputants are not incurred with any charges. Several studies have shown that Sulh bears no cost in reaching an agreement between disputants. This is infact one of the captivations that one shall look at, as it reduces the costs of resolving conflicts compared to the court-assisted method. For example in Brunei, in order to file a complaint of any issues be it matrimonial or marriage conflicts, the plaintiff will have to spend around $\$ 80-\$ 200$. In addition, if the issues are expanded and both plaintiff and defendant refuse to come to terms, charges will then be incurred upon them depending on the length of trials.

On the other side, in spite of bearing no cost during the Sulh session, this method also solves the disputes with a win-win situation for both parties. In Selangor, Rule 9 specifies that the parties to Majlis 
Sulh will bear no cost (Nora Abdu Hak, 2008).

"Rule 9. No cost."

No costs shall be charged for Majlis Sulh proceedings.

The same rule applies to Brunei Darussalam, where there will be no cost incurred upon the disputant parties throughout the whole process of Sulh session. This can be foundin theSyariah Courts Civil Procedure Order, 2005 under the Syariah Courts Civil Procedure (Sulh Rules), 2013, Rule number 11 stated that:

"No cost shall be allowed for a Majlis Sulh."

Based on the above rule, It shows that not only Sulhis effective but it also has provided fewer costs and lesser time in resolving disputes.

\section{Caucus Session}

It is undoubtedly true that the Sulh offers a win-win situation for both parties. Whereby, disputants are required to present their arguments in the caucus session as part of the procedures to extract any valuable informations that can help in identifying the root of the conflicts. Caucus session is where the disputants will be separated in a room to discuss their views and matters. This is done to get any "missing" informations and further to identify the underlying problems and disputes for both disputant parties. This session is included in the process because some disputants are quite reluctant to share their concerns with the presence of the other party. Thus, this is also a crucial process to listen and collect any informations that is not shared during the joint-meeting. Furthermore, it has been proven that Caucus session really distinct the idea of Sulh from other alternatives in the problem solving (Fuad, Jamilah 2003), (M.Kamenecka-Usova, 2014) and is really effective in bringing out the hidden "dissatisfactions" among disputants.

\section{Sulh Officer in Sulh Session}

In Sulh, a Sulh session or namely MajlisSulh is to be conducted by Sulh officer. This is infact the cornerstone of the whole system as it plays an important role in reducing the conflicts among the disputant parties. The third party intervention is an authorized personnel who is elected to be responsible in handling the matter neutrally. The role of this Sulhofficer is to examine the options for both sides,provided that both are willing to co-operate in reaching an agreement towards the end (Julien D.payne, 1984), (Hammad, N.D). In some cases, a third party is exempted and disputants may reach a settlement without involving others.

However, there are few ethical rules to be followed by Sulh officer when conducting Sulh session. For example, they are ought to be Just and impartial when dealing with the disputants. Apart from being 
just a facilitator, the Sulhofficers are not allowed to be biased in any circumstances.According to the rules, they are not the one who make the decisions for the disputants and not allowed to give one.In Malaysia, Code of ethics are provided by the Federal States to keep the SulhOfficer in track of what they are obliged to do. The ethical manual book which is aimed to give outline to the Sulh officers upon conducting the Sulh session. Below are part of the ethical codes they need abide by:

a. Title

The code of ethics shall be named as Code of Ethics for Sulh Officers

b. Application

1) The code of ethics shall be applicable to Sulh Officer during the tenure of his service.

2) Violation of any provision of this Code of Ethics may become ground for action to be taken

3) under The Public Officers (Conduct and Discipline) Regulation 1993 (PU (A) 395/93)

c. General Responsibility

1) A Sulh Officer is not allowed to:

a) Behave in such a manner that may cause reasonable doubt that: He has let personal interests in conflict with his official duties as a Sulh Officer, He has used his position for his own benefits;

b) Behave in a dishonest manner or in such a way that will aggravate and defile the good name of Shariah Court.

c) Neglect his duties in favour of self interest.

d) Freely mingle with people in a way that may raise doubts about his ability to be fair in his job.

e) Accept any gift when the gift in any way is related to the performance of his duties.

f) Undertake any job for getting wages for any institution, company, firm or individual without consent or clear permission by the Shariah Chief Judge.

g) Give an opinion on any matter or situation that is being discussed or is likely to be an issue in any Sulh session that is being held, as his opinion may later be used by any party to support their arguments.

h) Borrow money from any person, or be a guarantor to any borrower, or in any way put himself under any financial obligation to any person : Directly or indirectly subject to his sulh duties or with whom he has or may have official dealings, Take part in any activity in any political party. 
2) A Sulh Officer shall diligently, and not to delay without any reasonable excuse, settle any sulh case and obey directives issued by the Shariah Chief Judge from time to time.

3) A Sulh Officer shall in undertaking his duties administer justice as is required by Islamic Law.

4) A Sulh Officer shall always enhance his knowledge and skills.

d. Special responsibilities

1) When a Sulh Officer conducts a Sulh session, he shall:

a) Not conduct a Sulh session when he is not calm, angry, hungry, thirsty, sleepy, tired and sick;

b) Not leave the Sulh session as scheduled without reasonable excuse or without prior consent from the Shariah Chief Judge;

c) Not conduct a Sulh session where the parties involved is his enemy or friend who is likely to influence him;

d) Act firmly and fairly and not being influenced by circumstances or people who appear before him;

e) Be open, friendly and patient when handling the Sulh session;

f) Ensure that the proceedings of the Sulh session is run in an orderly manner according to Sulh Work Manual and control the situation so that the Sulh session is smoothly run;

g) Encourage the parties to resolve their disputes and reach an agreement voluntarily;

h) Give equal treatment to all parties involved.

2) ASulh Officer shall :

a) Be unbiased;

b) Always be neutral;

c) Keep confidential all matters disclosed in the Sulh session;

d) Avoid conflicts of interest;

e) Ensure that he has the skills or expertise in the subject matter of dispute;

f) Cannot advertise his services;

g) Refuse the application to be a witness or counsellor to the parties in the Sulhsessionwhich he has conducted before;

h) Ensure the safety of all parties in the Sulh session.

In addition, this system also adopt a confidential measure towards their clients' cases and arguments. This is because inSulh, the parties are given rights to keep their cases confidential unlike in courts which are most likely open for public. The confidentiality of their cases are to be kept at extreme measure that only the Chairman and disputant parties know about the details. Throughout the session, any papers 
written by the Chairman will be shredded afterwards and only the rulings of whether the case is successful or not will be shared to the court.

\section{Backlog of Cases}

Backlog of cases can be defined simply as the number of prolonged cases or cases that are taking too much time to be resolved in the court. This can be caused by several factors namely the availability of judges, the clash of cases, the presence of both plaintiff and defendants, and the lack of evidences. For instance, when both plaintiff and defendant still insist to fight their rights and present their cases before the judges, not only it is time consuming but also the longer they are resisting to a settlement the more their cases are being forwarded to the following months. Given that time allocations for most cases in court are around three to four months minimum, this will lead to the accumulation of backlog of cases in the court.

The Sulh method has proven to be a successful tool in reducing the accumulation of backlog of cases in the Selangor's Syariah court (Nora, 2008), (So'adah, 2015). This is because the settlement period is less consuming than court-assisted method. The settlement of the court-assisted method will definitely depend on many factors for example evidences, witnesses, presence of both parties and cooperations of both parties. However, in Sulh the settlement of the cases solely depend on the disputants themselves and the faster they reach agreement, the quicker the cases are resolved. Also, the sulh method has a three-month period of time to reach a settlement and if the disputants still fail to reach one, it will be carry forward to the court for trials.

\begin{tabular}{|l|l|l|l|}
\hline No. & $\begin{array}{l}\text { No. of Backlog } \\
\text { Cases }\end{array}$ & $\begin{array}{l}\text { No. of Settled Cases } \\
\text { via Sulh }\end{array}$ & The Difference \\
\hline 1. & 2555 & 1748 & 807 \\
\hline
\end{tabular}

No. of backlog cases May 2002- December 2003, Selangor Syariah court.

According to (Raihanah,2008), she stated that ever since the implementations of Sulh in the Selangor's syariah court, the back log of cases has been decreased from 2555 cases registered from May 2002 until December 2003, 1748 cases have been successfully settled through Sulh. This is undeniable that, Sulh gives a good fortune towards the Syariah Court especially in resolving cases efficiently. 


\section{CONCLUSION}

This method has proven very efficient and successful world wide. Not only the cost is extremely low but also the speed of settlement is what attracts both parties to consider this method as one of their disputes resolution. To add sugar to the coffee, the practice of Sulh has helped the Syariah court particularly in the reduction of backlog of cases and unclog their calendar. This can be seen from the statistic carried out by the past researcher. Furthermore, this method offers a win-win situation for both parties despite having another core strength of emphasizing the confidentiality of the cases in their method.

\section{REFERENCE}

Al-Quran, Surah An-Nisa (Verse: 35).

Al-Quran, Surah An-Nisa (Verse: 128).

An-Nawawi. Raudhatu At-Tolibin. Beirut: Dar Alkutub Al-Ilmiah, 1992.

At-Tirmidzi, Jami` at-Tirmidhi 1352, Vol.3, Book 15, Beirut : Dar Al-Fikr.

Aseel Al-Ramahi. Sulh: A Crucial Part of Islamic Arbitration,London School of Economics and Political Science Law Department, New York Law School, 2017.

Asmidah Ahmad. Hak Penyertaan Kanak-kanak Dalam Prosiding Sulh (Mediasi) di Mahkamah Syariah, University Sains Islam Malaysia (USIM), 2015.

Brunei Darussalam Government Gazette. P.432.

Hammad Mohammad Dahalan. Pengurusan Sulh: Peranan, Pelaksanaan dan keberkesanannya oleh Pegawai Sulh., Kolej Universiti Islam Antara bangsa Selangor (KUIS), 2014.

M. Kamenecka-Usova. mediation family dispute resolution, University of Latvia, 2014.

Mohd Fuad Mohd Salleh, Jamilah Othman. Peranan Pegawai Sulh Dalam Penyelesaian Konflik Keluarga Islam, Malaysia, 2003.

Nora Abdul Hak, Sa'odah Ahmad. Alternative Dispute Resolution (ADR) in Islam, IIUM printing sdn.bhd, Selangor Darul Ehsan, 2011.

Payne's Divorce and Family Law Digest Professor Julien D. Payne, Q.C., LL.D (1984). The Mediation of Family Dispute, 84-1861/1867.

Raihanah Azahari. Sulh dalam kekeluargaan Islam, Universiti Malaysia, University of Malaya, 2008.

So'adah Ahmad. Sulh: An Alternative Dispute Resolution and Amicable Settlement of Family Dispute, University Putra Malaysia, 2015.

SuhardiMahani. Punca dan Kesan Pertikaian Rumah Tangga Serta Kaedah Penyelesaiannya melalui Khidmat Nasihat. UNISSA, 2018. 
The Significance Of Sulh In The Syariah Court

https://www.esyariah.gov.bn/portals/syariah/branches/web/home/art icle_view $/ 282 / 239 ? 11=1 \& 12=1$

http://ww1.utusan.com.my/utusan/Bicara_Agama/20140102/ba_02/Ut amakan-mediasi-berbanding-litigasi

http://www.astroawani.com/berita-malaysia/kes-cerai-pasangan-islamdi-selangor-membimbangkan-217731

https://lokadata.beritagar.id/chart/preview/jumlah-perceraian-diindonesia-2014-2016-1510649052.

http://www.esyariah.gov.my/portal/page/portal/BI\%20Sulh/Code $\% 20$ of $\% 20$ Ethics $\% 20$ for $\% 20$ Sulh $\% 20$ Officers 
Nur Syasya Binti Rosiman

Halaman ini sengaja dikosongkan 